\title{
Analisis peranan usaha kerajinan rumah tangga dalam rangka penyerapan tenaga kerja dan membangun masyarakat ekonomi kecil di Kabupaten Bantul
}

\author{
Susianti \\ AMA Dharmala Yogyakarta, Indonesia \\ E-mail korespodensi: susianti.se@gmail.com
}

\begin{abstract}
This study aims to analyze the role of folk/household handicraft businesses in the context of employment and building a small economic community through the analysis of factors affecting the income of household craftsmen in the Bantul Regency. Problems that are still encountered in the household handicraft business are related to business activities carried out traditionally and the scale of business is still limited. So this has an impact on the amount of product produced is still limited, and indirectly the level of income is still low. To increase production efforts means the factors that support it are needed. Data sources used are primary data and secondary data. The quantitative analysis used is multiple regression analysis with the Ordinary Least Square (OLS) method. Based on the results of descriptive analysis, the main reason that encourages the craftsmen to run a household handicraft business in Bantul Regency is the main work to obtain and add income to meet their needs. And the household handicraft business plays a role in employment in Bantul Regency by 13.69\%. Meanwhile, based on the regression results, the variable of business capital and raw materials have positive and significant coefficients. Where business capital is the variable that has the most influence on the income of craftsmen household crafts in Bantul Regency.
\end{abstract}

Keywords: The role, Household crafts, Absorption of labor, Small economic community

\section{Abstrak}

Penelitian ini bertujuan untuk menganalisis peranan usaha kerajinan rakyat/rumah tangga dalam rangka penyerapan tenaga kerja dan membangun masyarakat ekonomi kecil melalui analisis faktor-faktor yang mempengaruhi pendapatan pengrajin rumah tangga yang ada di Kabupaten Bantul. Permasalahan yang masih dijumpai dalam usaha kerajinan rumah tangga adalah terkait dengan kegiatan usaha yang dilakukan secara tradisional dan skala usahanya masih terbatas. Sehingga ini berdampak pada jumlah produksi yang dihasilkan masih terbatas, dan secara tidak langsung tingkat pendapatannya masih rendah. Untuk meningkatkan usaha produksinya berarti dibutuhkan faktor-faktor yang menunjangnya. Sumber data yang digunakan adalah data primer dan data sekunder. Analisis kuantitatif yang digunakan adalah analisis regresi berganda dengan metode Ordinary Least Square (OLS). Berdasarkan hasil analisis deskriptif, alasan utama yang mendorong para pengrajin menjalankan usaha kerajinan rumah tangga di Kabupaten Bantul yaitu sebagai pekerjaan pokok untuk memperoleh dan menambah penghasilan guna mencukupi kebutuhan. Dan usaha kerajinan rumah tangga berperan dalam penyerapan tenaga kerja di Kabupaten Bantul sebesar 13,69\%, Sedangkan, berdasarkan hasil regresi, variabel modal usaha dan bahan baku memiliki koefisien positif dan signifikan. Dimana modal usaha merupakan variabel yang mempunyai pengaruh paling besar terhadap pendapatan pengrajin usaha kerajinan rumah tangga di Kabupaten Bantul.

Kata kunci: Peranan, Kerajinan rumah tangga, Penyerapan tenaga kerja, Masyarakat ekonomi kecil 


\section{PENDAHULUAN}

Bangsa Indonesia selama ini senantiasa melaksanakan pembangunan guna meningkatkan taraf hidup masyarakat yang masih rendah. Taraf hidup masyarakat tercermin dari tingkat pendapatan per kapita masyarakat. Masyarakat kita masih banyak yang menggantungkan hidupnya pada sektor pertanian. Pemerintan telah mengusahakan adanya kemajuan serta peningkatan pendapatan dari sektor ini tanpa mengabaikan sektor yang lain. Hal ini dimaksudkan untuk tercapainya perkembangan yang selaras, serasi dan seimbang dalam semua sektor kehidupan.

Salah satu sektor yang mendapat perhatian untuk dikembangkan dalam konteks pembangunan ekonomi Indonesia adalah sektor industri. Pembangunan ekonomi pada hakekatnya adalah salah satu proses perubahan secara terus menerus guna meningkatkan pendapatan per kapita dan kenaikan itu harus terus berlangsung dalam jangka panjang sehingga taraf hidup masyarakat akan meningkat (Arsyad, 2010). Pembangunan sering dikaitkan dengan proses industrialisasi karena keduanya dianggap mempunyai pengertian yang sama. Proses industrialisasi dan pembangunan kesejahteraan rakyat dalam arti tingkat hidup yang lebih bermutu. Selain itu industri juga merupakan suatu sektor pemimpin karena industri tersebut merangsang dan mendorong investasi-investasi di sektor lain. Pembangunan industri di Indonesia diupayakan untuk mengembangkan potensi yang ada melalui pemanfaatan sumber daya alam dan sumber daya lainnya secara optimal. Pembangunan industri tidak hanya ditujukan untuk industri besar saja tetapi juga industri menengah, industri kecil, dan industri mikro (UMKM).

Besarnya perhatian pemerintah terhadap berkembangnya industri kecil termasuk industri kerajinan dan industri rumah tangga karena sebagian besar industri kecil berada di pedesaaan. Ini disebabkan oleh kenyataan bahwa jumlah tenaga yang semakin meningkat, sedangkan luas lahan pertanian semakin sempit. Sehingga diharapkan industri kecil ini bisa menjadi salah satu jalan keluar untuk meningkatkan pendapatan dan mengerahkan tenaga kerja, dan lebih jauh lagi diharapkan dapat mengurangi arus urbanisasi. Selain itu juga industri kecil mempunyai peranan yang penting bagi perekonomian Indonesia.

Menurut Saleh (1986), industri kecil mempunyai manfaat sosial (social benefits) sebagai berikut: 1).Industri kecil dapat menciptakan peluang berusaha yang luas dengan pembiayaan yang relatif murah. 2)Industri kecil turut mengambil peranan dalam peningkatan dan motivasi tabungan domestik. 3)Industri kecil mempunyai kedudukan komplementer terhadap industri besar dan sedang, karena industri kecil menghasilkan produk yang relatif murah dan sederhana, yang biasanya tidak dihasilkan oleh industri besar dan sedang.

Data BPS DIY (2018) menunjukkan bahwa pertumbuhan produksi Industri Mikro Kecil (IMK) D.I. Yogyakarta triwulan I tahun 2017 terhadap triwulan IV tahun 2016 (qto-q) mengalami pertumbuhan positif, yaitu sebesar 3,64 persen. Pertumbuhan pada triwulan I 2017 ini sejalan dengan angka pertumbuhan produksi industri mikro kecil di tingkat nasional yang mengalami pertumbuhan positif sebesar 2,44 persen. Sedangkan pertumbuhan produksi Industri Mikro Kecil (IMK) D.I. Yogyakarta triwulan I tahun 2017 terhadap triwulan I tahun 2016 (y-on-y) mengalami pertumbuhan positif, yaitu sebesar 10,54 persen. Kenaikan pertumbuhan produksi di D.I. Yogyakarta lebih tinggi jika dibandingkan dengan angka pertumbuhan di tingkat nasional, yang tumbuh sebesar 6,63 persen 
Menurut Kuncoro (2012), kontribusi aktivitas industri setiap provinsi di Jawa terhadap total jumlah tenaga kerja pada tahun 1976 -1995 relatif lebih tinggi jika dibandingkan dengan provinsi atau pulau lainnya di Indonesia. Sedangkan untuk Kabupaten Bantul, sektor industri mempunyai peranan penting dalam pertumbuhan ekonomi dan penyerapan tenaga kerja. Meskipun sektor pertanian masih dominan (lihat Tabel 1.1) namun dalam perkembangannya kurang mampu untuk meningkatkan pendapatan dan menyediakan lapangan kerja sebagai salah satu alternatif.

Tabel 1. Persentase penduduk usia 10 tahun ke atas yang bekerja menurut lapangan pekerjaan utama dan jenis kelamin di kabupaten bantul

\begin{tabular}{|c|c|c|}
\hline No. & Lapangan Pekerjaan & Persentase \\
\hline 1. & Pertanian & 25,56 \\
\hline 2. & Pertambangan dan Penggalian & 1,98 \\
\hline 3. & Industri & 18,95 \\
\hline 4. & Listrik, gas dan air & 0,07 \\
\hline 5. & Konstruksi & 8,88 \\
\hline 6. & Perdagangan & 21,16 \\
\hline 7. & Komunikasi/transportasi & 4,64 \\
\hline 8. & Keuangan & 1,61 \\
\hline 9. & Jasa & 16,89 \\
\hline 10. & Lainnya & 0,27 \\
\hline & Jumlah & 100,00 \\
\hline
\end{tabular}

Sumber: BPS Kabupaten Bantul, 2018(diolah)

Secara umum, industri yang terdapat di Kabupaten Bantul merupakan industri kecil, sedangkan industri besar jumlah tidak banyak. Perkembangan industri kecil menengah dapat dilihat pada tabel di bawah ini:

Tabel 2. Perkembangan industri kecil menengah di Kabupaten Bantul 2011-2014

\begin{tabular}{llcccc}
\hline \multirow{2}{*}{ No } & \multirow{2}{*}{ Uraian } & \multicolumn{4}{c}{ Tahun } \\
\cline { 3 - 6 } & & $\mathbf{2 0 1 1}$ & $\mathbf{2 0 1 2}$ & $\mathbf{2 0 1 3}$ & $\mathbf{2 0 1 4}$ \\
\hline 1. & Unit Usaha & 18.158 & 18.235 & 18.295 & 18.391 \\
2. & Tenaga Kerja & 81.905 & 81.938 & 81.998 & 82.961 \\
3. & Nilai Produksi & 800.105 .10 & 800.295 .40 & 800.312 .100 & 829.112 .200 \\
& (Rp.00000 ribuan) & 0 & 0 & & \\
4. & Nilai Tambah & 509.266 .78 & 509.465 .40 & 509.525 .400 & 512.405 .400 \\
& (Rp. ribuan) & 0 & 0 & & \\
5. & Nilai Investasi & 488.715 .80 & 488.862 .20 & 488.905 .130 & 493.801 .130 \\
& (Rp. ribuan) & 0 & 0 & & \\
\hline
\end{tabular}

Sumber: Disperindagkop, 2015(diolah)

Berdasarkan Tabel 2. menunjukkan bahwa untuk unit usaha industri kecil dan menengah di Kabupaten Bantul mengalami perkembangan dari 2011-2014. Di mana pada tahun 2011 jumlah unit usaha sebesar 18.158 dan pada tahun 2014 menjadi 18.391. dan 
jumlah tenaga kerja yang terserap dalam kurun waktu 2011-2014 juga meningkat, dari 81.905 orang pada tahun 2011 menjadi 82.961 orang pada tahun 2014.

Selanjutnya pada Tabel 3 menunjukkan bahwa Komoditas terpilih untuk industri di Kabupaten Bantul meliputi tiga kategori, yaitu komoditas unggulan, andalan, dan diunggulkan (lihat Tabel 3). Dari Tabel 3 di atas bisa dilihat bahwa masing-masing komoditas pilihan di daerah Kabupaten Bantul sudah merupakan produk ekspor. Dilihat dari peluang untuk berkembang, industri kecil khususnya kerajinan rakyat/rumah tangga diperkirakan mempunyai potensi yang cukup besar akan dapat semakin berkembang cepat. Walaupun hal ini tidak akan lepas dari adanya hambatan-hambatan untuk perkembangannya. Dalam upaya untuk mengatasi hambatan-hambatan tersebut terlebih dahulu diperhatikan faktor-faktor yang diduga mempengaruhi dalam produksi industri kerajinan yang bersangkutan. Sehingga dengan berkembangnya usaha kerajinan di Kabupaten Bantul sangat diharapkan bisa meningkatkan pendapatan dan penyerapan tenaga kerja dalam upaya meningkatkan kesejahteraan masyarakat ekonomi kecil, khususnya rumah tangga pengrajin di Kabupaten Bantul

Tabel 3. Komoditas industri terpilih Kabupaten Bantul Tahun 2014

\begin{tabular}{|c|c|c|c|c|c|c|c|c|}
\hline \multirow[b]{2}{*}{$\begin{array}{l}\text { Kelompok } \\
\text { Industri }\end{array}$} & \multirow[b]{2}{*}{ Lokasi } & \multirow[b]{2}{*}{$\begin{array}{c}\text { Bahan } \\
\text { Baku } \\
\text { Lokal } \\
(\%)\end{array}$} & \multirow{2}{*}{$\begin{array}{l}\text { Tenag } \\
\text { a } \\
\text { Kerja } \\
\text { (Org) }\end{array}$} & \multicolumn{5}{|c|}{ Ekspor } \\
\hline & & & & $\begin{array}{l}\text { Nilai } \\
\text { (US\$ } \\
\text { Juta) }\end{array}$ & $\begin{array}{c}\% \\
\text { Total } \\
\text { Ekspor }\end{array}$ & $\begin{array}{l}\text { Gro } \\
\text { wth } \\
(\%) \\
\end{array}$ & Negara Tujuan & Trend \\
\hline \multicolumn{9}{|c|}{ Unggulan : } \\
\hline $\begin{array}{l}\text { Kerajinan } \\
\text { Kulit }\end{array}$ & $\begin{array}{l}\text { Imogiri, } \\
\text { Bantul }\end{array}$ & 100 & 3.112 & $\begin{array}{l}15,39 \\
7\end{array}$ & 26,72 & 6 & $\begin{array}{l}\text { UK, Perancis, } \\
\text { USA, Belanda }\end{array}$ & naik \\
\hline $\begin{array}{l}\text { Mebel } \\
\text { Kayu }\end{array}$ & $\begin{array}{l}\text { Bantul, } \\
\text { Sewon, } \\
\text { Kasihan, } \\
\text { Banguntapan } \\
\text {, Sedayu, } \\
\text { Bambanglipu } \\
\text { ro }\end{array}$ & 100 & 6.587 & 4,489 & 7,72 & 6,2 & $\begin{array}{l}\text { Jerman, } \\
\text { Perancis, } \\
\text { USA, Turki }\end{array}$ & naik \\
\hline \multicolumn{9}{|l|}{ Andalan: } \\
\hline $\begin{array}{l}\text { Produk } \\
\text { Tekstil/ } \\
\text { Batik }\end{array}$ & & 100 & 2.740 & 3,140 & 5,54 & 6,3 & $\begin{array}{c}\text { Australia,Pera } \\
\text { ncis, USA, } \\
\text { Jerman, Turki }\end{array}$ & naik \\
\hline $\begin{array}{l}\text { Kerajinan } \\
\text { Batu dan } \\
\text { Gerabag }\end{array}$ & $\begin{array}{l}\text { Kasihan, } \\
\text { Piyungan, } \\
\text { Banguntapan }\end{array}$ & 100 & 5.203 & 1,223 & 2,12 & 6 & $\begin{array}{l}\text { Korea, } \\
\text { Inggris, } \\
\text { Belanda, } \\
\text { Vietnam, } \\
\text { Thailand }\end{array}$ & naik \\
\hline \multicolumn{9}{|c|}{ Diunggulkan: } \\
\hline $\begin{array}{l}\text { Kerajinan } \\
\text { Kertas }\end{array}$ & & 85 & 4.214 & 3,469 & 6,02 & 5,8 & $\begin{array}{c}\text { Korea, } \\
\text { Belanda, } \\
\text { USA, Jerman, } \\
\text { Turki, UK }\end{array}$ & naik \\
\hline
\end{tabular}

Sumber: Disperindagkop, 2015(diolah)

\section{METODE}

Daerah penelitian ini berlokasi di Kabupaten Bantul. Pemilihan daerah penelitian ini dikaitkan dengan potensi yang ada di daerah ini dalam pengembangan usaha industri 
kerajinan khususnya kerajinan rumah tangga. Sumber data merupakan faktor penting yang menjadi menjadi pertimbangan dalam menentukan metode pengumpulan data. Data yang digunakan dalam penelitian ini bersumber dari data primer dan data sekunder.

Data primer diperoleh dengan survei secara langsung ke lapangan menggunakan semua metode pengumpulan data orisinal dari responden. Metode pengumpulan data primer ini dilakukan dengan wawancara personal (personal interviewing) terstruktur yang dipandu dengan menggunakan pertanyaan-pertanyaan atau kuesioner kepada responden yang terpilih menjadi sampel penelitian yang diarahkan oleh pewancara untuk tujuan memperoleh informasi yang relevan untuk menjawab masalah penelitian. Selain itu, peneliti juga melakukan pendekatan dengan menggunakan pengamatan langsung terhadap obyek (survei) yang akan dijadikan sumber penelitian. Adapun jenis data yang digunakan meliputi: modal usaha, pendidikan, umur, jam kerja, dan pendapatan usaha.

Untuk data sekunder data diperoleh secara tidak langsung oleh peneliti melalui perantara. Dalam hal ini, peneliti mendapatkan data sekunder dari BPS dan dokumendokumen lainnya dari berbagai instansi pemerintah yang terkait. Hasil penelitian terdahulu dan beberapa hasil, dilakukan oleh peneliti untuk melakukan pencarian (browsing) di internet sebagai data sekunder yang dapat digunakan sebagai perbandingan dan masukan dalam mengadakan analisis.

\section{Penentuan dan pengambilan sampel penelitian}

Dalam pengambilan sampel penulis menggunakan probabilitas sampling yang memberikan kemungkinan yang sama bagi setiap unsur dalam populasi untuk dipilih. Sedangkan metode yang dipakai dalam penentuan sampel tersebut adalah random sampling. Sampel random berarti bahwa anggota dari populasi mempunyai kesempatan yang sama untuk dapat dipilih sebagai sampel sehingga diharapkan sampel ini obyektif.

Responden penelitian ini ditentukan dengan metode purposive sampling dengan menentukan tingkat presisi melalui error maksimum sebesar 0,20 dengan tingkat keyakinan 95\%. Penelitian ini menggunakan nilai kritis sebesar 20\% sehingga jumlah sampel yang diperoleh sudah cukup mewakili keadaan populasi tersebut. Maka jumlah sampel dapat ditentukan dengan rumus sebagai berikut: (Djarwanto, 1994)

$$
\begin{aligned}
& \mathrm{n}=(1,96: E)^{2} \\
& \mathrm{n}=(1,96: 0,20)^{2} \\
& \mathrm{n}=100
\end{aligned}
$$

Sehingga besarnya sampel yang diambil berjumlah 100 responden. Kemudian diikuti dengan menggunakan judgmental sampling, yaitu tehnik pengambilan sampel berdasarkan judgment atau pertimbangan tertentu, dimana peneliti menggunakan pertimbangan tertentu dalam memilih anggota populasi sebagai sampel (Istijanto, 2006).

\section{Definisi operasional variabel penelitian}

Penelitian ini menggunakan variabel dependen dan variabel independen. Variabel dependen adalah variabel yang menjadi perhatian utama dalam sebuah pengamatan, sedangkan variabel independen adalah variabel yang dapat mempengaruhi hubungan positif ataupun yang negatif bagi variabel dependen nantinya (Kuncoro, 2013).

Penelitian ini menggunakan variabel pendapatan sebagai variabel dependen, sedangkan variabel modal usaha, curahan jam kerja, bahan baku, dan bahan pembantu sebagai variabel independen. Adapun definisi operasional dari masing-masing variabel dapat dilihat pada Tabel 4 berikut ini: 
Tabel 4. Definisi operasional variabel penelitian

\begin{tabular}{|c|c|c|c|}
\hline Variabel & Penjelasan & Hipotesis & Satuan \\
\hline $\begin{array}{l}\text { Pendapatan } \\
\text { pengrajin }\end{array}$ & $\begin{array}{l}\text { Hasil yang diterima dari jumlah } \\
\text { seluruh penerimaan selama satu } \\
\text { bulan dikurangi dengan biaya } \\
\text { pengeluaran operasi. }\end{array}$ & $\begin{array}{l}\text { Pendapatan pengrajin dapat } \\
\text { ditingkatkan dengan modal } \\
\text { usaha, curahan jam kerja, } \\
\text { bahan baku, bahan pembantu. }\end{array}$ & Rupiah \\
\hline $\begin{array}{l}\text { Modal } \\
\text { Usaha }\end{array}$ & $\begin{array}{l}\text { Junlah uang yang digunakan } \\
\text { untuk mengusahakan unit usaha } \\
\text { kerajinan. }\end{array}$ & $\begin{array}{l}\text { Variabel modal usaha diduga } \\
\text { berpengaruh terhadap } \\
\text { pendapatan usaha kerajinan } \\
\text { rumah tangga. }\end{array}$ & Rupiah \\
\hline $\begin{array}{l}\text { Curahan } \\
\text { Jam Kerja }\end{array}$ & $\begin{array}{l}\text { Lamanya waktu yang digunakan } \\
\text { untuk menjalankan usaha } \\
\text { kerajinan. Dimulai dari sejak } \\
\text { persiapan bahan baku sampai } \\
\text { menghasilkan output. . Jam kerja } \\
\text { dihitung dalam waktu bulanan. }\end{array}$ & $\begin{array}{l}\text { Variabel curahan jam kerja } \\
\text { diduga berpengaruh terhadap } \\
\text { pendapatan usaha kerajinan } \\
\text { rumah tangga. }\end{array}$ & Jam \\
\hline $\begin{array}{l}\text { Bahan } \\
\text { Baku }\end{array}$ & $\begin{array}{l}\text { Bahan utama untuk membuat } \\
\text { produk dalam suatu proses } \\
\text { produksi. Biaya bahan baku } \\
\text { merupakan harga pokok dari } \\
\text { bahan baku yang diolah dalam } \\
\text { proses produksi. }\end{array}$ & $\begin{array}{l}\text { Variabel bahan baku diduga } \\
\text { berpengaruh terhadap } \\
\text { pendapatan usaha kerajinan } \\
\text { rumah tangga }\end{array}$ & Rupiah \\
\hline $\begin{array}{l}\text { Bahan } \\
\text { Pembantu }\end{array}$ & $\begin{array}{l}\text { Bahan yang digunakan sebagai } \\
\text { penunjang kelengkapan dalam } \\
\text { proses produksi. Bahan pembantu } \\
\text { ini diperlukan untuk melengkapi } \\
\text { desain yang diinginkan. }\end{array}$ & $\begin{array}{l}\text { Variabel bahan Pembantu } \\
\text { diduga berpengaruh terhadap } \\
\text { pendapatan usaha kerajinan } \\
\text { rumah tangga. }\end{array}$ & Rupiah \\
\hline
\end{tabular}

Sumber: Penulis, 2018(diolah)

\section{Metode analisis data}

Dalam rangka menganalisis data yang telah terkumpul guna menguji hipotesis yang telah dirumuskan, maka digunakan metode analisis kualitatif dan metode analisis kuantitatif.

\section{Analisis kualitatif}

Analisis ini digunakan untuk menguji dan menilai setiap informasi dari data denganlogika yang mengacu pada teori-teori yang ada, berupa uraian, keterangan, ulasan, dan pendapat.

\section{Analisis kuantitatif}

Analisis ini digunakan untuk menguji dan menilai setiap data yang terkumpul dengan menggunakan rumus-rumus yang diambil dari buku teks yang mengupas teori yang bersangkutan. Analisis kuantitatif yang digunakan adalah analisis persamaan regresi berganda. Regresi ini digunakan untuk menganalisis data yang sifatnya multivariate, untuk meramalkan nilai variabel dependen (Y) dengan variabel independen yang lebih dari satu, karena variabel yang mempengaruhi kondisi (X) dalam mempengaruhi variabel dependen (Y) bervariasi, bisa positif tetapi bisa juga negatif, atau beraneka ragam kondisi yang mempengaruhi. Sehingga regresi berganda ini lebih riil dengan kenyataan di 
lapangan. Sedangkan untuk membuktikan hubungan fungsional atau hubungan kausal antara beberapa variabel (X1, X2, X3, X4) mempengaruhi variabel dependen (Y) dapat diukur dengan uji statistik.

Estimasi suatu garis regresi dilakukan dengan jalan meminimalkan jumlah dari kuadrat kesalahan setiap observasi terhadap garis tersebut yang disebut dengan metode Ordinary Least Square (Kuncoro, 2013). Alat analisis yang akan digunakan dalam penelitian ini adalah SPSS 20,0. Penggunaan model regresi linear berganda ini ditujukan untuk mengetahui pengaruh modal usaha, curahan jam kerja, bahan baku, dan bahan pembantu terhadap pendapatan pengrajin industri kerajinan / industri rumah tangga. Formula model dasarnya yaitu (Widarjono, 2013: 59) :

Keterangan:

$$
\mathrm{Y}=\beta_{0}+\beta_{1} \mathrm{X}_{1}+\beta_{2} \mathrm{X}_{2}+\beta_{3} \mathrm{X}_{3}+\beta_{4} \mathrm{X}_{4}+\mathrm{e}
$$

$\mathrm{Y} \quad=$ Pendapatan Pengrajin

$\mathrm{X} 1=$ Modal Usaha

$\mathrm{X} 2=$ Jam Kerja

$\mathrm{X} 3=$ Bahan Baku

$\mathrm{X} 4=$ Bahan Pembantu

$\mathrm{e} \quad=$ Error term

$\beta_{0} \quad=$ Konstanta dari persamaan regresi

$\beta_{1}-\beta_{4}=$ Koefisien Regresi X1,X2,X3,X4

\section{Pengujian statistik}

Ketepatan fungsi regresi sampel dalam menaksir nilai aktual dapat diukur dari goodness of fit-nya. Secara statistik, setidaknya ini dapat diukur dari nilai: koefisien deterministic, Nilai statistik F, Nilai statistik t

\section{Koefisien determinasi}

Koefisien determinasi $\left(\mathrm{R}^{2}\right)$ pada intinya mengukur seberapa jauh kemampuan model dalam menerangkan variasi variabel dependen. Nilai koefisien determinasi adalah antara nol dan satu (Ghozali, 2011:97). Nilai $\mathrm{R}^{2}$ yang kecil berarti kemampuan variabel-variabel independen dalam menjelaskan variasi variabel dependen amat terbatas. Nilai yang mendekati satu berarti variabel-variabel independen memberikan hampir semua informasi yang dibutuhkan untuk memprediksi variasi variabel dependen (Kuncoro, 2013: 246).

Oleh karena itu, penelitian ini menggunakan nilai Adjusted $R^{2}$ pada saat mengevaluasi mana model regresi yang terbaik. Tidak seperti $\mathrm{R}^{2}$, nilai Adjusted $R^{2}$ dapat naik atau turun apabila satu variabel independen ditambahkan kedalam model (Ghozali, 2011).

\section{Nilai statistik F}

Uji statistik F pada dasarnya menunjukkan apakah semua variabel bebas (independen) yang dimasukkan dalam model mempunyai pengaruh secara bersama-sama terhadap variabel terikat (Kuncoro, 2013: 245). Cara untuk menguji hipotesis digunakan statistik F dengan kriteria pengambilan keputusan Quick Look, yaitu apabila nilai F lebih besar daripada 4 maka Ho dapat ditolak pada derajat kepercayaan $5 \%$. Hal ini berarti menerima hipotesis alternatif, yang menyatakan bahwa semua variabel independen secara serentak dan signifikan mempengaruhi variabel dependen (Kuncoro, 2013: 245). 


\section{Nilai statistik t}

Uji statistik t pada dasarnya menunjukkan seberapa jauh pengaruh suatu variabel penjelas secara individual dalam menerangkan variasi variabel terikat. Cara melakukan uji t menggunakan Quick Look, yaitu melihat angka signifikansinya. Apabila angka signifikan > 0,05, maka Ho diterima dan Ha ditolak, apabila angka signifikansi $<0,05$ maka Ho ditolak dan Ha diterima dan (Kuncoro, 2013: 244).

\section{HASIL DAN PEMBAHASAN}

\section{Karakteristik sosial ekonomi responden}

Berdasarkan data primer yang diperoleh dari 100 orang responden, maka diperoleh karakteristik umum responden yang melakukan usaha kerajinan rumah tangga di Kabupaten Bantul berdasarkan pendapatan, modal usaha, curahan jam kerja, bahan baku, dan bahan pembantu, dijelaskan terkait dengan karakteristik responden berdasarkan pendapatan, karakteristik responden berdasarkan modal usaha, karakteristik responden berdasarkan bahan baku,

\section{Karakteristik responden berdasarkan pendapatan}

Pendapatan diukur dengan melihat hasil yang diterima dari jumlah seluruh penerimaan selama satu bulan dikurangi dengan biaya-biaya produksi.

Tabel 5.Karakteristik responden berdasarkan pendapatan

\begin{tabular}{lc}
\hline Pendapatan (rupiah) & Banyaknya responden \\
\hline$<2.500 .000$ & 28 \\
$2.500 .000-7.500 .000$ & 46 \\
$>7.500 .000$ & 26 \\
\hline Total & 100 \\
\hline
\end{tabular}

Sumber: Data diolah, 2018

Berdasarkan Tabel 5. menunjukkan banyaknya pendapatan bersih yang diterima oleh responden dalam penelitian ini selama satu (1) bulan. Pendapatan responden kurang dari Rp 2.500.000,- selama satu (1) bulan sebanyak 28 orang responden, selanjutnya pendapatan responden berkisar antara Rp 2.500.000-, sampai dengan Rp 7.500.000-, selama satu (1) bulan sebanyak 46 orang responden, dan sisanya pendapatan responden diatas $\mathrm{Rp} 7.500 .000$,- selama satu (1) bulan sebanyak 26 orang responden. Sehingga dapat disimpulkan bahwa responden yang mempunyai pendapatan berkisar antara Rp. 2.500.000,- - Rp. 7.500.000,- selama satu (1) bulan merupakan responden yang paling banyak pada penelitian ini. Adapun rata-rata penghasilan bersih adalah sebesar Rp. $6.732 .500,-$

\section{Karakteristik responden berdasarkan modal usaha}

Modal usaha dalam penelitian ini didefinisikan sebagai jumlah uang yang digunakan untuk menjalankan usaha kerajinan rumah tangga. Berdasarkan Tabel 6. menunjukkan modal usaha yang diperlukan oleh responden dalam menjalankan usaha rumah tangganya. Modal usaha responden kurang dari Rp 2.500.000,- untuk menjalankan usaha kerajinan rumah tangga sebanyak 13 orang responden, selanjutnya modal usaha berkisar antara Rp 2.500.000-, sampai dengan Rp 7.500.000-, selama satu (1) bulan sebanyak 23 orang responden, dan sisanya modal usaha responden di atas $\mathrm{Rp} 7.500 .000,-$ 
untuk menjalankan usaha kerajinan rumah tangga sebanyak 64 orang responden. Sehingga dapat disimpulkan bahwa modal usaha yang diperlukan oleh responden dalam menjalankan usaha kerajinan rumah tangga paling banyak berjumlah di atas Rp.7.500.000,- sebanyak 64 orang responden. Sumber modal berasal dari modal mereka sendiri, bukan bersumber pada pinjaman. Di mana rata-rata modal usaha pengrajin usaha kerajinan rumah tangga adalah sebesar Rp. 18.194.500,-.

Tabel 6. Karakteristik responden berdasarkan modal usaha

\begin{tabular}{lc}
\hline Modal usaha (rupiah) & Banyaknya responden \\
\hline$<2.500 .000$ & 13 \\
$2.500 .000-7.500 .000$ & 23 \\
$>7.500 .000$ & 64 \\
\hline Total & 100 \\
\hline
\end{tabular}

Sumber: Data diolah, 2018

\section{Karakteristik responden berdasarkan bahan baku}

Bahan baku dalam penelitian ini didefinisikan sebagai jumlah uang yang digunakan untuk mengadakan bahan utama membuat produk dalam suatu proses produksi usaha kerajinan rumah tangga. Biaya bahan baku merupakan harga pokok dari bahan baku yang diolah dalam proses produksi.

Tabel 7. Karakteristik responden berdasarkan bahan baku

\begin{tabular}{lc}
\hline Bahan baku (Rupiah) & Banyaknya responden \\
\hline$<2.500 .000$ & 36 \\
$2.500 .0-7.500 .000$ & 46 \\
$>7.500 .000$ & 17 \\
\hline Total & $\mathbf{1 0 0}$ \\
\hline
\end{tabular}

Sumber: Data diolah, 2018

Berdasarkan Tabel 7 menunjukkan bahan baku yang diperlukan oleh responden dalam menjalankan usaha kerajinan rumah tangga. Bahan baku responden kurang dari Rp 2.500.000,- untuk mengusahakan usaha kerajinan rumah tangga sebanyak 36 responden, selanjutnya bahan baku berkisar antara Rp 2.500.000-, sampai dengan Rp 7.500.000-, selama satu (1) bulan sebanyak 46 responden, dan sisanya bahan baku responden di atas Rp 7.500.000,- untuk mengusahakan usaha kerajinan rumah tangga sebanyak 17 responden. Dapat disimpulkan, bahwa bahan baku yang diperlukan oleh responden dalam menjalankan usaha kerajinan rumah tangga paling banyak yaitu di atas Rp. 7.500.000sebanyak 46 responden.

\section{Karakteristik responden berdasarkan bahan pembantu}

Bahan pembantu dalam penelitian ini didefinisikan sebagai jumlah uang yang digunakan untuk mengadakan bahan penunjang kelengkapan dalam proses produksi. Bahan pembantu ini diperlukan untuk melengkapi desain yang diinginkan dalam usaha kerajinan rumah tangga. Berdasarkan Tabel 8 menunjukkan bahan pembantu yang diperlukan oleh responden dalam menjalankan usaha kerajinan rumah tangga. Bahan pembantu responden kurang dari Rp 2.500.000,- untuk menjalankan usaha kerajinan rumah tangga sebanyak 79 responden, selanjutnya bahan pembantu berkisar antara Rp 2.500.000-, sampai dengan Rp 7.500.000-, selama satu (1) bulan sebanyak 18 responden, 
dan sisanya bahan pembantu responden di atas Rp 7.500.000,- untuk menjalankan usaha kerajinan rumah tangga sebanyak 3 responden. Dapat disimpulkan, bahwa bahan pembantu yang diperlukan oleh responden dalam menjalankan usaha kerajinan rumah tangga paling banyak yaitu kurang dari Rp 2.500.000,- sebanyak 79 responden.

Tabel 8. Karakteristik responden berdasarkan bahan pembantu

\begin{tabular}{cc}
\hline Bahan pembantu (Rupiah) & Banyaknya responden \\
\hline $\mathbf{2 . 5 0 0 . 0 0 0}$ & 79 \\
$\mathbf{2 . 5 0 0 . 0 0 0}-\mathbf{7 . 5 0 0 . 0 0 0}$ & 18 \\
$>\mathbf{7 . 5 0 0 . 0 0 0}$ & 3 \\
\hline Total & $\mathbf{1 0 0}$ \\
\hline
\end{tabular}

Sumber: Data diolah, 2018

\section{Karakteristik responden berdasarkan curahan jam kerja}

Jam kerja dalam penelitian ini diukur dengan lamanya waktu yang digunakan untuk menjalankan usaha kerajinan rumah tangga. Jam kerja dalam penelitian ini dihitung dalam waktu bulanan, dimana satu (1) bulan diasumsikan selama 25 hari.

Tabel 9. Karakteristik responden berdasarkan curahan jam kerja

\begin{tabular}{cc}
\hline Jam kerja $(\mathbf{j a m} /$ bulan$)$ & Banyaknya responden \\
\hline$<200$ & 39 \\
$200-400$ & 61 \\
$>400$ & 0 \\
\hline Total & $\mathbf{1 0 0}$
\end{tabular}

Sumber: Data diolah, 2018

Berdasarkan Tabel 9 menunjukkan jam kerja responden pada usaha kerajinan rumah tangga. Ada 39 orang responden yang memiliki jam kerja yang kurang dari 200 jam per bulan. Selanjutnya, ada 61 orang responden yang memiliki jam kerja berkisar 200 sampai dengan 400 jam per bulan. Dan tidak ada responden yang memiliki jam kerja lebih dari 400 jam kerja per bulan. Sehingga dapat disimpulkan bahwa pengrajin usaha rumah tangga di Kabupaten Bantul termasuk golongan yang bekerja penuh yaitu mereka yang tenaganya dimanfaatkan dalam bekerja dan memiliki jam kerja berkisar antara $200-400$ jam kerja per bulan atau rata-rata 46 jam/minggu.

Curahan jam kerja para pengrajin dalam sehari antara $6-8$ jam, hal ini karena mereka bekerja di industri kerajinan rumah tangga yang merupakan pekerjaan pokok/utama mereka. Biasanya mereka bekerja mulai pagi hari sampai sore hari dan kebanyakan usaha kerajinannya dilakukan di rumah.

\section{Besaran kontribusi dan pendapatan pengrajin usaha kerajinan rumah tangga di Kabupaten Bantul}

Dalam penelitian ini, pendapatan pengrajin yang tertinggi adalah sebesar Rp. 80.000.000,- per bulannya. Sedangkan pendapatan yang terendah sebesar Rp. 1.000.000,. Dan rata-rata pendapatan yang diperoleh pengrajin usaha kerajinan rumah tangga di Kabupaten Bantul setiap bulannya sebesar Rp. 6.732.500,-Pendapatan pengrajin usaha kerajinan rumah tangga di Kabupaten Bantul yang menjadi responden dalam penelitian ini hampir seluruhnya bersumber dari hasil kegiatan usaha kerajinan rumah tangga yang mereka jalankan. Hanya 19 orang dari 100 orang responden yang menjadikan usaha kerajinan usaha rumah tangga ini sebagai usaha sampingan. Hal ini menunjukkan bahwa hampir semua pengrajin bergantung pada kegiatan usaha kerajinan rumah tangga ini 
untuk memenuhi kebutuhan hidup dan menjadi tumpuan hidup untuk keluarganya. Kontribusi dan pendapatan usaha pengrajin kerajinan rumah tangga di Kabupaten Bantul dijelaskan dengan menggunakan analisis deskriptif sebagai berikut:

Tabel 10. Kontribusi pendapatan usaha pengrajin kerajinan rumah tangga di Kabupaten Bantul

\begin{tabular}{ccc}
\hline Pendapatan (Rupiah) & Banyaknya responden & Persentase \\
\hline$<2.500 .000$ & 28 & $28 \%$ \\
$2.500 .000-7.500 .000$ & 46 & $46 \%$ \\
$>7.500 .000$ & 26 & $26 \%$ \\
\hline Total & $\mathbf{1 0 0}$ & $\mathbf{1 0 0 \%}$ \\
\hline
\end{tabular}

Sumber: Data diolah, 2018

Berdasarkan Tabel 10 menunjukkan hasil kontribusi pendapatan pengrajin usaha kerajinan rumah tangga di Kabupaten Bantul. Besarnya kontribusi pendapatan rumah tangga yang diterima oleh responden dalam sebulan kurang dari Rp 2.500.000,- sebanyak $28 \%$, selanjutnya sebanyak $46 \%$ memberikan kontribusi pendapatan untuk rumah tangganya sebesar Rp 2.500.000,- sampai dengan Rp 7.500.000,-. Sisanya sebanyak 26\% memberikan kontribusi pendapatan rumah tangga lebih dari Rp 7.500.000,- per bulannya. Sehingga bisa disimpulkan bahwa mayoritas pengrajin pengrajin dari usaha kerajinan rumah tangga mempunyai pendapatan pada kategori pendapatan yang berkisar Rp. 2.500.000,- sampai dengan Rp. 7.500.000,- per bulan (46\%). Pendapatan pengrajin yang berbeda-beda ini dikarenakan beberapa faktor, antara lain adanya perbedaan faktor produksi, skala usaha, lamanya usaha, dan jenis kelompok industri yang berbeda.

Dengan demikian, Pendapatan yang didapat pengrajin tersebut bisa digunakan untuk mengetahui seberapa besar kontribusi pendapatan tersebut terhadap pendapatan total pengrajin. Selanjutnya, bisa menjelaskan bahwa pendapatan pengrajin yang seluruhnya didapatkan dari hasil kegiatan usaha kerajinan tanpa ada sumber pendapatan lain maka dapat menunjukkan besarnya kontribusi dari usaha kerajinan rumah tangga sebesar $100 \%$. Hal ini membukikan kebenaran dari hipotesis penelitian ini yang menyatakan ada kontribusi yang besar dari pendapatan usaha kerajinan rumah tangga terhadap pendapatan total pengrajin usaha kerajinan rumah tangga di Kabupaten Bantul.

Data lain yang diperoleh dari hasil penelitian mendukung kondisi tersebut. Di mana dari data di dapat bahwa alasan yang mendorong pengrajin melakukan kegiatan usaha kerajinan rumah tangga antara lain karena tidak ada pekerjaan lain (pekerjaan pokok), menambah penghasilan keluarga untuk mencukupi kebutuhan, dan warisan orang tua. Sehingga bisa dipastikan bahwa pendapatan pengrajin seluruhnya didapat dari hasil kegiatan usaha kerajinan yang mereka jalankan.

Selanjutnya, berdasarkan Gambar 1 menunjukkan alasan pengrajin melakukan usaha kerajinan rumah tangga di Kabupaten Bantul. Dari 100 responden yang terpilih untuk dijadikan sampel penelitian, terdapat tiga (3) alasan utama seorang pengarjin memilih untuk melakukan usaha kerajinan rumah tangga, yaitu Pertama menambah penghasilan keluarga untuk mencukupi kebutuhan, Kedua tidak ada pekerjaan lain, dan Ketiga usaha tersebut merupakan warisan dari orang tua. Dari hasil kuesioner tersebut, $49 \%$ dari responden (49 orang) mengatakan bahwa alasan utama memutuskan menjalankan usaha kerajinan rumah tangga dikarenakan untuk menambah penghasilan keluarga untuk mencukupi kebutuhan. Selanjutnya sebanyak 32\% responden (32 orang) mengatakan bahwa alasan utama mereka memutuskan menjalankan usaha kerajinan rumah tangga 
disebabkan karena memang tidak ada pekerjaan lain, dan sisanya sebanyak 19\% responden (19 orang) mengatakan bahwa alasan utama mereka untuk memutuskan menjalankan usaha kerajinan rumah tangga karena meneruskan usaha warisan orang tua.

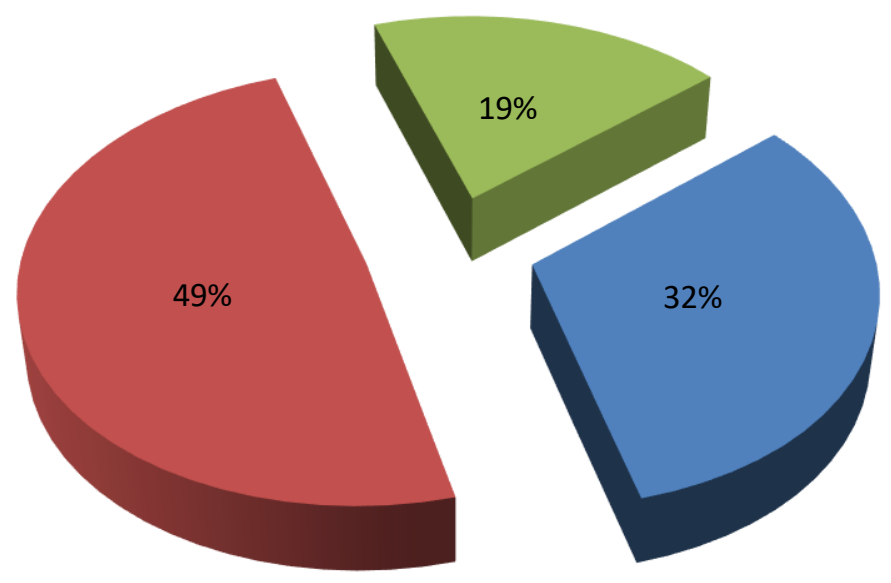

- Tidak ada pekerjaan lain $\quad$ Menambah penghasilan

Sumber: Data diolah, 2018

Gambar 1. Alasan pengrajin menjalankan usaha kerajinan rumah tangga di Kabupaten Bantul

\section{Peranan usaha kerajinan rumah tangga terhadap penyerapan tenaga kerja di Kabupaten Bantul}

Peranan usaha kerajinan rumah tangga terhadap penyerapan tenaga kerja dapat dilihat dari Tingkat Kesempatan Kerja (Iriyanto, 2017). Tingkat Kesempatan Kerja adalah salah satu ukuran ketenagakerjaan yang sering dan banyak digunakan untuk melihat tingkat penyerapan tenaga kerja.

Berkaitan dengan penyerapan tenaga kerja, pengrajin memiliki tenaga kerja yang berasal dari keluarga dan non keluarga. Jumlah anggota keluarga/ rumah tangga yang terlibat dalam kegiatan produksi kerajinan rumah tangga rata-rata sekitar berkisar antara $1-3$ orang. Dari 100 orang pengrajin mampu melibatkan 110 anggota keluarga/rumah tangga sebagai tenaga kerja. Sehingga total yang terlibat dalam kegiatan usaha kerajinan rumah tangga sebanyak 210 orang. Sedangkan tenaga kerja yang non keluarga yang bisa terlibat sebanyak 147 orang

Peranan usaha kerajinan rumah tangga di Kabupaten Bantul dalam penelitian ini diketahui dari Tingkat Kesempatan Kerja (Iriyanto, 2017). Perhitungannnya dengan cara membandingkan jumlah angkatan kerja di industri kerajinan rumah tangga (usaha mikro, kecil dan menengah) dengan jumlah angkatan kerja di Kabupaten Bantul berdasarkan data Statistik Penduduk DIY tahun 2018, sebagai berikut:

$$
\begin{aligned}
\mathrm{TKK} & =\frac{\text { Jumlah angkatan kerja di industri kerajinan rumah tangga }}{\text { Jumlah angkatan kerja di Kabupaten Bantul }} \times 100 \% \\
\mathrm{TKK} & =\frac{76.995}{562.296} \times 100 \%=13,69 \%
\end{aligned}
$$

Berdasarkan hasil perhitungan dapat disimpulkan bahwa usaha kerajinan rumah tangga berperan dalam penyerapan tenaga kerja di Kabupaten Bantul sebesar $13.69 \%$.. 
Hal ini berdasarkan pertimbangan utama adanya pengalaman kerja. Dapat disimpulkam bahwa dari 100 pengrajin mampu melibatkan 357 orang dalam kegiatan usaha kerajinannya. Berarti untuk 21.567 unit usaha kerajinan rumah tangga yang termasuk dalam data industri mikro, kecil dan menengah (Dinas Koperasi, Usaha Kecil, Menengah, dan Perindustrian Kabupaten Bantu, 2018) dapat melibatkan tenaga kerja sebanyak 76.995 orang.

\section{Pengujian model estimasi faktor-faktor yang mempengaruhi pendapatan pengrajin usaha kerajinan rumah tangga}

Pengujian model dengan uji diagnostic ekonometrika dilakukan untuk mendapatkan model estimasi yang baik yang akan digunakan. Dengan uji ini dapat diketahui apakah koefisien regresi hasil estimasi sudah terbebas dari permasalahan dengan asumsi klasik BLUE (Best, Linear, Unbiased, Estimator). Dalam penelitian ini, uji diagnostic ekonometrika yang dilakukan meliputi uji multikolonieritas, autokorelasi, dan heteroskedastisitas dengan menggunakan level signifikansi $\alpha=5$ persen, sebagai berikut:

\section{Uji multikolonieritas}

Multikolonieritas bertujuan untuk menguji apakah model regresi ditemukan adanya korelasi antar variabel bebas (independen). Sehingga dari Uji Multikolonieritas ini dapat diketahui situasi atau keberadaan dari hubungan linear yang "sempurna", atau tepat, diantara sebagian atau seluruh variabel independen dalam sebuah model regresi.

Tabel 11. Nilai tolerance, VIF

\begin{tabular}{lcc}
\hline \multicolumn{1}{c}{ Variabel } & Tolerance & VIF \\
\hline Modal usaha & $0,167^{*}$ & $5,985^{*}$ \\
Jam kerja & $0,938^{*}$ & $1.066^{*}$ \\
Bahan baku & $0,109^{*}$ & $9.182^{*}$ \\
Bahan pembantu & $0,227^{*}$ & $4.410^{*}$
\end{tabular}

Sumber: Data diolah, 2018

Keterangan:

Dasar pengambilan keputusan multikolonieritas:

- Nilai Tol. > 0,10, maka tidak ada multikolonieritas

- Nilai VIF < 10, maka tidak ada multikolonieritas

Ada atau tidaknya multikolonieritas di dalam model estimasi regresi dideteksi dengan cara melihat nilai dari tolerance (Tol) dan variance inflation factor (VIF). Dimana baik nilai Tol maupun VIF menunjukkan bahwa setiap variabel independen mana yang dijelaskan oleh variabel independen lainnya. Tolerance mengukur variabilitas variabel independen yang terpilih yang tidak dijelaskan oleh variabel independen lainnya. Nilai tolerance yang rendah sama dengan nilai variance inflation factor yang tinggi (karena $\mathrm{VIF}=1 /$ tolerance). Adapun aturan baku yang umum dipakai untuk menunjukkan adanya multikolonieritas adalah nilai tolerance $(\mathrm{Tol})<0,10$ atau sama dengan nilai VIF suatu variabel $\geq 10$ (melebihi 10 ).

Hasil perhitungan yang ditunjukkan dalam Tabel 4.7, nilai tolerance > 0,10 yang berarti tidak ada korelasi antar variabel independen yang nilainya lebih dari $95 \%$. Kemudian, dari nilai variance inflation factor (VIF) $<10$ menunjukkan hal yang sama 
bahwa tidak ada satupun variabel independen yang memiliki nilai VIF > 10. Jadi dapat disimpulkan bahwa tidak ada multikolonieritas antarvariabel independen dalam model estimsi regresi.

\section{Uji autokorelasi}

Dalam penelitian ini, uji autokorelasi dilakukan untuk mendeteksi apakah dalam model regresi linear ada korelasi antar kesalahan pengganggu pada periode $t$ dengan kesalahan pengganggu pada periode t-1 (sebelumnya). Dari hasil Uji Durbin-Watson (DW Test) menunjukkan bahwa nilai sebesar 1,814 (lihat Lampiran 5). Nilai 1,814 ini akan dibandingkan dengan nilai tabel yang menggunakan nilai signifikansi $\alpha=5 \%$, jumlah sampel $100(\mathrm{n})$ dan jumlah variabel independen $4(\mathrm{k}=4)$, maka di tabel DW akan didapat nilai sebagai berikut: $\mathrm{n}=100, \mathrm{k}=4, \mathrm{dL}=1,5922$ dan $\mathrm{dU}=1,7582$. Oleh karena nilai $\mathrm{DW}=1,814$ lebih besar dari batas atas $(\mathrm{dU})=1,7582$ dan kurang dari $(4-\mathrm{dU})$ atau $4-$ $1,7582=2,2418$, maka dapat disimpulkan bahwa Ho yang menyatakan bahwa tidak ada autokorelasi positif ataupun negatif tidak bisa ditolak (H0 diterima) atau dapat disimpulkan tidak terdapat autokorelasi dalam model estimasi regresi.

\section{Uji heteroskedastisitas}

Uji heteroskedastisitas bertujuan untuk mengetahui apakah dalam model regresi terjadi ketidaksamaan variance dari residual satu pengamatan ke pengamatan yang lain (Ghozali, 2011). Situasi homoskedastisitas terjadi jika semua memiliki varians yang sama dari observasi satu ke observasi lain, sedangkan situasi heteroskedastisitas terjadi jika semua memiliki varians yang tak sama, atau non konstan dari observasi satu ke observasi lain. Model regresi yang baik adalah yang homoskedastisitas atau tidak terjadi heteroskedastisitas.

Uji glejser dilakukan untuk mendeteksi ada atau tidaknya heteroskedastisitas. Dimana Uji Glejser mengusulkan untuk meregres nilai absolut residual terhadap variabel independen (Ghozali, 2011). Adapun dasar yang digunakan dalam menentukan pengambilan keputusan, sebagai berikut: 1).Probabilitas signifikansinya di atas $>0,05$ atau 5\%, maka tidak ada heteroskedastisitas, 2).Probabilitas signifikansinya di bawah < 0,05 atau 5\%, maka ada heteroskedastisitas.

Tabel 12. Nilai tolerance, VIF, dan signifikansi

\begin{tabular}{lccc}
\hline \multicolumn{1}{c}{ Variabel } & Tolerance & VIF & Sig. \\
\hline Modal usaha & 0,167 & 5,985 & 0,520 \\
Jam kerja & 0,938 & 1,066 & 0,121 \\
Bahan baku & 0.109 & 9,182 & 0.397 \\
Bahan pembantu & 0.227 & 4,410 & 0.427
\end{tabular}

Sumber: Data diolah, 2018

Berdasarkan Tabel 12 menunjukkan hasil pengujian heteroskedastisitas. Jika variabel independen signfikan secara statistik mempengaruhi variabel dependen, maka ada indikasi terjadi heteroskedastisitas. Hasil output SPSS yang diringkas pada Tabel 12 menunjukkan bahwa tidak ada satupun variabel independen yang signifikan secara statistik mempengaruhi variabel dependen dalam nilai Absolut unstandardized residual (AbsUt). Hal ini terlihat dari probabilitas signifikansi semua variabel independen tidak ada yang bernilai di bawah tingkat kepercayaan 5\%. Artinya, dapat disimpulkan bahwa tidak ada heteroskedastisitas dalam model estimasi regresi. 


\section{Pengujian statistik}

Ketepatan model estimasi regresi dalam menaksir nilai aktual dapat diukur dari goodness of fit-nya. Secara statistik, setidaknya ini dapat diukur dari nilai koefisien determinasi, nilai statistik F, dan nilai statistik t. (Kuncoro, 2001).

Tabel 13. Hasil estimasi koefisien regresi, adjusted R square, nilai F-hitung, sig. variabel pada pendapatan wanita di Kabupaten Sleman

\begin{tabular}{|c|c|c|c|}
\hline Variabel & Koefisien & Std. Error & Sig. \\
\hline Konstanta & $-910722,978$ & 3326517,578 & 0,785 \\
\hline Modal Usaha & 0,115 & 0,036 & $0.002 *$ \\
\hline Jam Kerja & 10149,467 & 17968,511 & 0,574 \\
\hline Bahan Baku & 1,067 & 0,185 & $0.000 *$ \\
\hline Bahan Pembantu & $-0,604$ & 0,415 & 0.149 \\
\hline \multicolumn{4}{|c|}{ Adjusted $R$ Square $=0.832$} \\
\hline
\end{tabular}

Keterangan: *= Signifikan pada $\alpha=5 \%$

Sumber: Data diolah, 2018

\section{Uji statistik t}

Uji statistik t pada dasarnya menunjukkan seberapa jauh pengaruh suatu variabel independen secara individual (parsial) dalam menerangkan variasi variabel dependen. Berdasarkan Tabel 13, dengan melihat probabilitas signifikansinya, maka tidak semua variabel independen signifikan dalam model. Variabel yang signifikan dapat dilihat dari sig. pada $\alpha=5 \%$, yaitu modal usaha mempunyai signifikansi sebesar $0,002(<0,05)$, bahan baku mempunyai signifikansi sebesar $0,000(<0,05)$. Jadi dapat disimpulkan bahwa modal usaha dan bahan baku yang berpengaruh secara signifikan terhadap pendapatan pengrajin usaha kerajinan rumah tangga. Hasil regresi yang ditunjukkan pada Tabel 13 dapat diinterpretasikan sebagai berikut:

\section{Nilai konstanta}

Nilai konstanta dari hasil estimasi regresi dalam penelitian ini adalah 910.7222,978. Artinya jika tidak terdapat variabel modal usaha, jam kerja, bahan baku, dan bahan pembantu, maka variabel pendapatan pengrajin usaha kerajinan rumah tangga di Kabupaten Bantul akan tetap ada dengan nilai yang negatif sebesar 910.7222,978 pada tingkat kepercayaan 95 persen.

\section{Modal usaha}

Berdasarkan hasil estimasi regresi memperlihatkan bahwa variabel modal memiliki tanda koefisien yang positif sebesar 0,115 . Hal ini mengandung arti bahwa apabila modal usaha pengrajin mengalami peningkatan sebesar $\mathrm{Rp}, 1,-$, maka dapat menaikkan pendapatan pengrajin sebesar Rp. 0,115,-- Nilai probabilitas modal usaha pada tabel 13 sebesar 0,002, artinya dengan tingkat kepercayaan 95 persen dan asumsinya jam kerja, bahan baku, dan bahan pembantu konstan maka variabel modal berpengaruh positif dan signifikan terhadap pendapatan pengrajin usaha kerajinan rumah tangga di Kabupaten Bantul.

\section{Curahan jam kerja}

Berdasarkan hasil estimasi regresi memperlihatkan bahwa jam kerja yang dimiliki oleh pengrajin memiliki tanda koefisien yang positif sebesar 10.149,467. Hal ini mengandung arti apabila jam kerja mengalami peningkatan sebesar 1 jam/bulan, maka 
dapat menaikkan pendapatan wanita sebesar Rp. 10.149,467,-- Nilai probabilitas jam kerja pada tabel 13 sebesar 0,574, artinya dengan tingkat kepercayaan 95 persen dan asumsinya modal usaha, bahan baku, dan bahan pembantu konstan, maka variabel jam kerja berpengaruh positif dan tidak signifikan terhadap pendapatan pengrajin usaha kerajinan rumah tangga di Kabupaten Bantul.

\section{Bahan baku}

Berdasarkan hasil estimasi regresi memperlihatkan bahwa variabel bahan baku pengrajin memiliki tanda koefisien yang positif sebesar 1,067. Hal ini mengandung arti apabila bahan baku pengrajin mengalami peningkatan sebesar Rp. 1,-, maka dapat meningkatkan pendapatan pengrajin sebesar Rp. 1,067,-. Nilai probabilitas bahan baku pada tabel 13 sebesar 0,000, artinya dengan tingkat kepercayaan 95 persen dan asumsinya modal usaha, jam kerja, dan bahan pembantu konstan, maka variabel bahan baku berpengaruh positif dan signifikan terhadap pendapatan pengrajin usaha kerajinan rumah tangga di Kabupaten Bantul

\section{Bahan pembantu}

Berdasarkan hasil estimasi regresi memperlihatkan bahwa bahan pembantu yang dimiliki oleh pengrajin memiliki tanda koefisien yang negatif sebesar 0,604 . Hal ini mengandung arti apabila bahan pembantu yang digunakan pengrajin mengalami peningkatan sebesar Rp.1,-, maka dapat menurunkan pendapatan pengrajin tersebut sebesar Rp. 0,604,-. Nilai probabilitas bahan pembantu pada tabel 13 sebesar 0,149, artinya dengan tingkat kepercayaan 95 persen dan asumsinya modal usaha, jam kerja, dan bahan baku konstan, maka variabel bahan pembantu berpengaruh negatif dan tidak signifikan terhadap pendapatan pengrajin usaha kerajinan rumah tangga di Kabupaten Bantul.

\section{Uji statistik F}

Uji statistik F pada dasarnya menunjukkan apakah semua variabel bebas (independen) yang dimasukkan dalam model mempunyai pengaruh secara bersama-sama terhadap variabel terikat (dependen).

Hasil uji ANOVA atau $\mathrm{F}$ test yang diringkas pada tabel 13 menunjukkan nilai $\mathrm{F}$ hitung sebesar 123,220 dengan probabilitas 0,000. Nilai probabilitas tersebut jauh lebih kecil dari taraf signifikansi sebesar 0,05. Hal ini berarti model estimasi regresi dapat digunakan untuk memprediksi pendapatan pengrajin atau dapat dikatakan bahwa variabel independen (modal usaha, jam kerja, bahan baku, dan bahan pembantu) secara bersamasama berpengaruh secara signifikan terhadap pendapatan pengrajin usaha kerajinan rumah tangga di Kabupaten Bantul.

\section{Pengujian determinasi}

Koefisien determinasi $\left(\mathrm{R}^{2}\right)$ pada intinya mengukur seberapa jauh kemampuan model dalam menerangkan variasi variabel dependen. Nilai koefisien determinasi adalah antara nol dan satu. Nilai $\mathrm{R}^{2}$ yang kecil berarti kemampuan variabel-variabel independen dalam menjelaskan variasi variabel dependen amat terbatas. Nilai yang mendekati satu berarti variabel-variabel independen memberikan hampir semua informasi yang dibutuhkan untuk memprediksi variasi variabel dependen.

Berdasarkan hasil ringkasan output SPSS model summary pada Tabel 13, besarnya nilai Adjusted R square adalah 0,832. Hal ini berarti 83,2 persen variabel dependen (pendapatan pengrajin usaha kerajinan rumaha tangga) dapat dijelaskan oleh variasi dari ke empat variabel independen, yaitu: modal, jam kerja, bahan baku, dan bahan pembantu sedangkan sisanya sebesar 16,8 persen dijelaskan oleh sebab-sebab yang lain di luar model. 


\section{Analisis pengaruh modal usaha, jam kerja, bahan baku, dan bahan pembantu terhadap pendapatan pengrajin usaha kerajinan rumah tangga di Kabupaten Bantul}

Berdasarkan hasil estimasi dengan regresi linear berganda, maka pengaruh modal usaha, jam kerja, bahan baku, dan bahan pembantu terhadap pendapatan pengrajin usaha kerajinan rumah tangga di Kabupaten Bantul dapat dirumuskan sebagai berikut:

$$
Y=-910722,978+0,115 X 1 *+10149,467 X 2+1,067 X 3 *-0,6042 X 4
$$

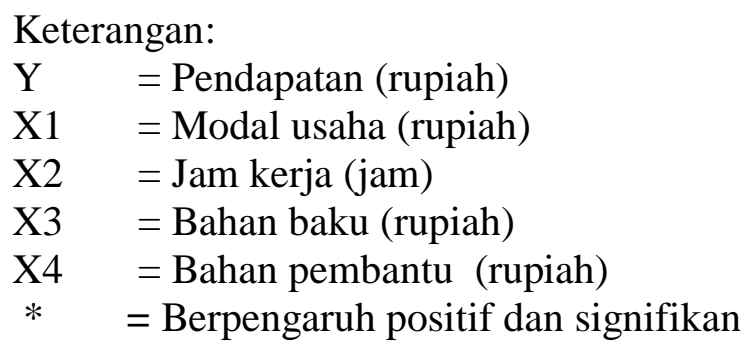

Interpretasi hasil estimasi regresi pengaruh modal usaha, jam kerja, bahan baku, dan bahan pembantu terhadap pendapatan pengrajin usaha kerajinan rumah tangga di Kabupaten Bantul yang mempunyai hubungan signifikan ataupun tidak signifikan adalah sebagai berikut:

\section{Modal usaha}

Berdasarkan hasil estimasi memperlihatkan bahwa variabel modal usaha memiliki tanda koefisien yang positif sebesar 0,115 . Hal ini mengandung arti bahwa apabila modal usaha pengrajin mengalami peningkatan sebesar Rp.1,- maka dapat menaikkan pendapatan pengrajin sebesar Rp. $0,115,-$. Nilai probabilitas modal usaha sebesar 0,002 berarti variabel modal usaha berpengaruh positif dan signifikan terhadap pendapatan pengrajin usaha kerajinan rumah tangga di Kabupaten Bantul.

Hasil ini sesuai dengan hipotesis penelitian ke-3 yang menyatakan bahwa ada pengaruh signifikan baik secara parsial maupun simultan variabel modal usaha terhadap pendapatan pengrajin usaha kerajinan rumah tangga. Dan juga sejalan dengan hasil penelitian dari I Nyoman (2015) dan I Putu (2016) yang menyatakan modal usaha berpengaruh positif pada pendapatan wanita karena setiap peningkatan modal usaha maka diikuti meningkatnya jumlah pendapatan yang diperoleh oleh wanita di sektor informal di Kabupaten Sleman.

\section{Curahan jam kerja}

Berdasarkan hasil estimasi regresi memperlihatkan bahwa jam kerja yang dimiliki oleh pengrajin mempunyai koefisien yang bertanda positif sebesar 10149,467. Hal ini mengandung arti apabila jam kerja mengalami peningkatan sebesar 1 jam/bulan, maka dapat menaikkan pendapatan pengrajin sebesar Rp. 10.149,467,-. Nilai probabilitas jam kerja sebesar 0,574 mempunyai arti bahwa variabel jam kerja berpengaruh positif dan tidak signifikan terhadap pendapatan pengrajin usaha kerajinan rumah tangga di Kabupaten Bantul.

Hasil ini tidak sesuai dengan hipotesis penelitian ke-3 yang menyatakan bahwa ada pengaruh signifikan baik secara parsial maupun simultan variabel jam kerja terhadap pendapatan pengrajin usaha rumah tangga di Kabupaten Bantul. Dan hasil ini tidak sejalan dengan hasil penelitian Susianti (2000), yang menyatakan bahwa bahan baku 
berpengaruh positif dan signifikan terhadap pendapatan pengrajin kulit dan pengrajin gerabah di Kabupaten Bantul.

\section{Bahan baku}

Berdasarkan hasil estimasi regresi memperlihatkan bahwa variabel bahan baku yang digunakan pengrajin memiliki koefisien yang bertanda positif sebesar 1,067. Hal ini mengandung arti apabila bahan baku pengrajin mengalami peningkatan sebesar Rp. 1,-, maka dapat meningkatkan pendapatan pengrajin sebesar Rp. 1,067,-. Nilai probabilitas bahan baku sebesar 0,000 mempunyai arti bahwa variabel bahan baku berpengaruh positif dan signifikan terhadap pendapatan wanita di Kabupaten Sleman.

Hasil ini sesuai dengan hipotesis penelitian ke-3 yang menyatakan bahwa ada pengaruh signifikan secara parsial maupun simultan variabel bahan baku terhadap pendapatan pengrajin usaha kerajinan rumah tangga di Kabupaten Bantul. Dan juga sejalan dengan hasil penelitian Susianti (2000) yang menyatakan bahwa bahan baku berpengaruh positif dan signifikan terhadap pendapatan pengrajin kulit dan pengrajin gerabah di Kabupaten Bantul.

Dari koefisien estimasi yang dihasilkan sebesar 1,067, menunjukkan bahwa bahan baku mempunyai pengaruh yang paling besar terhadap pendapatan pengrajin dibandingkan dengan variabel jam kerja, bahan baku dan bahan pembantu. Dan hasil ini tidak sesuai dengan hipotesis penelitian ke-4 yang menyatakan bahwa variabel modal usaha merupakan variabel yang mempunyai pengaruh paling besar terhadap pendapatan pengrajin usaha kerajinan rumah tangga di Kabupaten Bantul.

\section{Bahan pembantu}

Berdasarkan hasil estimasi regresi memperlihatkan bahwa bahan pembantu yang dimiliki oleh pengrajin mempunyai koefisien yang bertanda negatif sebesar 0,604 . Hal ini mengandung arti apabila bahan pembantu mengalami peningkatan sebesar Rp.1,-, maka dapat menurunkan pengrajin sebesar Rp. 0,604,-. Nilai probabilitas bahan pembantu sebesar 0,149 mempunyai arti bahwa variabel bahan pembantu berpengaruh negatif dan tidak signifikan terhadap pendapatan pengrajin usaha kerajinan rumah tangga di Kabupaten Bantul.

Hasil ini tidak sesuai dengan hipoteis penelitian ke-3 yang menyatakan bahwa ada pengaruh signifikan secara parsial maupun simultan variabel bahan baku terhadap pendapatan pengrajin usaha kerajinan rumah tangga di Kabupaten Bantul. Dan juga tidak sejalan dengan hasil penelitian Susianti (2000) yang menyatakan bahwa bahan baku berpengaruh positif dan signifikan terhadap pendapatan pengrajin kulit dan pengrajin gerabah di Kabupaten Bantul.

\section{KESIMPULAN DAN SARAN}

\section{Kesimpulan}

Usaha kerajinan rumah tangga di Kabupaten Bantul sebagian besar merupakan kegiatan usaha turun temurun, sehingga usaha ini dijadikan sebagai pekerjaan pokok dan tumpuan harapan untuk memenuhi segala kebutuhan hidup sehari-hari. Oleh karena itu kegiatan usahanya banyak dipengaruhi oleh latar belakang masyarakatnya, lingkungan sosial, unsur budaya, sistem mata pencarian yang terbatas, dan keadaan tata sosial masyarakat yang saling mendukung antaranggota keluarga maupun antaranggota masyarakat.

Ada kontribusi pendapatan usaha kerajinan rumah tangga terhadap pendapatan total pengrajin usaha kerajinan rumah tangga di Kabupaten Bantul, maka dapat diambil 
kesimpulan bahwa pendapatan pengrajin yang seluruhnya didapatkan dari hasil kegiatan usaha kerajinan tanpa ada sumber pendapatan lain maka dapat menunjukkan besarnya kontribusi dari usaha kerajinan rumah tangga sebesar $100 \%$.

Ada peran usaha kerajinan rumah tangga terhadap penyerapan tenaga kerja di Kabupaten Bantul. Hal ini dapat dibuktikan dengan hasil perhitungan yang menunjukkan bahwa usaha kerajinan rumah tangga berperan dalam penyerapan tenga kerja di Kabupaten Bantul sebesar 13,6.

Setelah dilakukan pengujian hipotesis yang ketiga yaitu faktor-faktor yang mempengaruhi pendapatan pengrajin usaha kerajinan rumah tangga, dapat disimpulkan bahwa:Dari keempat faktor yang mempengaruhi pendapatan pengrajin, yaitu modal usaha, jam kerja, bahan baku, dan bahan pembantu, hanya modal usaha dan bahan baku memberikan pengaruh yang positif dan signifikan terhadap pendapatan pengrajin. Artinya apabila modal usaha dan bahan baku ditambah penggunaannya, maka akan meningkatkan pendapatan pengrajin usaha kerajinan rumah tangga. Faktor bahan baku mempunyai pengaruh yang paling besar terhadap pendapatan pengrajin usaha kerajinan rumah tangga.

\section{Saran}

Pengembangan usaha kerajinan rumah tangga harus terus diusahakan karena usaha ini mampu menyerap tenaga kerja. Usaha ini dapat menyediakan lapangan pekerjaan bagi penduduk sekitarnya dan untuk selanjutnya dapat menghasilkan pendapatan yang berguna dalam memenuhi kebutuhan hidup pengrajin.

Pembinaan yang intensif kepada para pengrajin, baik mengenai manajemen produksinya, manjemen keuangan, pemasaran, maupun administrasi manajemennya sangat dibutuhkan dalam upaya peningkatan dan pengembangan industri mikro kecil menengah kerajinan rumah tangga. Sehingga perlu adanya kerjasama yang baik dengan instansi-instansi terkait, dalam hal ini Dinas Koperasi, UMKM dan Perindustrian.

Peranan Koperasi dan lembaga keuangan baik swasta maupun pemerintah perlu ditingkatkan guna menunjang terselenggaranya kegiatan pemberian kredit untuk mengatasi keterbatasan jumlah modal yang dimiliki oleh pengrajin, sehingga pendapatan pengrajin dapat ditingkatkan. Dengan meningkatnya pendapatan maka diharapkan akan meningkatkan kesejahteraan para pengrajin serta memberikan kontribusi pada pendapatan daerah dan nasional yang selanjutkan akan berdampak dalam membangun masyarakat ekonomi kecil.

Penggunaan tenaga kerja pada usaha kerajinan usaha rumah tangga perlu ditingkatkan jumlah dan kualitasnya melalui perbaikan kualitas SDM yang terampil sehingga keuntungan yang akan diperoleh dapat lebih ditingkatkan dan pada akhirnya akan meningkatkan pendapatan para pengrajin.

Pengrajin perlu lebih meningkatkan jenis dan desain produksi yang dihasilkan, agar produk yang dihasilkan tersebut meningkat nilai tambahnya. Dengan demikian peranan bahan baku dan bahan pembantu terhadap pendapatan lebih meningkat, sehingga peningkatan jumlah bahan baku dan bahan pembantu ini akan meningkatkan jumlah pendapatan dengan proporsi yang lebih besar dari sebelumnya.

\section{DAFTAR PUSTAKA}

Arsyad, L. (2010). Ekonomi Pembangunan, UPP STIM YKPN: Yogyakarta.

Badan Pusat Statistik. (2018). Data Industri. Kabupaten Bantul, Diakses dalam https://bantulkab.bps.go.id, Tanggal 06 Maret 2018.Pukul 14.20 WIB 
Ghozali, I. (2011). Aplikasi Analisis Multivariate Dengan Program IBM SPSS 19, Universitas Diponegoro: Semarang.

Gilarso, T. (1986). Ekonomi Indonesia Sebuah Pengantar, Kanisius: Yogyakarta.

Irawan., \& Suparmoko. (1992). Ekonomika Pembangunan, Edisi Kelima, BPFE: Yogyakarta.

Iriyanto, M.T. (2017). Peranan Industri Kerajinan Kulit Terhadap Pendapatan Rumah Tangga dan Penyerapan Tenaga Kerja di Dusun Manding, Desa Sabdodadi, Kecamatan Bantul, Kabupaten bantul. Jurnal Pendidikan dan Ekonomi, 6(6): 552564.

Istijanto. (2006). Riset Sumber Daya Manusia, Cara Praktis Mendeteksi Dimensi-dimensi Kerja Karyawan, Gramedia Pustaka Utama: Jakarta.

Kuncoro, M. (2012). Ekonomika Aglomerasi: Dinamika \& Dimensi Spasial Kluster Industri Indonesia. Edisi Pertama, UPP STIM YKPN: Yogyakarta.

Kuncoro, M. (2013). Metode Riset untuk Bisnis \& Ekonomi : Bagaimana Meneliti \& Menulis Tesis. Edisi 4, Erlangga: Jakarta.

Mubyarto. (1988). Peluang Kerja dan Berusaha di Pedesaan, BPFE: Yogyakarta.

Putra, I.P.D., Sudirman., \& I Wayan. (2015). Pengaruh Modal dan Tenaga Kerja Terhadap Pendapatan dengan Lama Usaha Sebagai Variabel Moderating. EJurnal Ekonomi Pembangunan Universitas Udayana, 4( 9),1048-1193.

Saleh, I.A. (1986). Industri Kecil Sebuah Tinjauan dan Perbandingan, LP3ES: Jakarta.

Setiawan, A.H. (2011). Perekonomian Indonesia. Universitas Diponegoro: Semarang.

Sevilla, C. G.,et.al. (2007). Research Methods, Rex Printing Company: Quezon City.

Soekartawi. (1990). Teori Ekonomi Produksi, Rajawali Pers: Jakarta.

Sukirno, S. (2010). Pengantar Teori Mikroekonomi. Edisi Kedua, PT Raja Grafindo Persada: Jakarta.

Susianti. (2000). Analisis Perbandingan Pendapatan Pengrajin Gerabah dan Pengrajin Kulit; Studi Kasus Desa Bangunjiwo dan Desa Sabdodadi Kabupaten Bantul, Skripsi. Tidak dipublikasi.

Tri, W., I Nyoman,G.; Widanta, A.A., \& Bagus, P. (2016). Pengaruh Modal Usaha dan Tenaga Kerja Terhadap Pendapatan dengan Kredit sebagai Variabel Moderasi pada Pedagang di Pasar Seni Sukawati. E-Jurnal Ekonomi Pembangunan Universitas Udayana, 5(11). 1168-1187

Widarjono, A. (2013). Ekonometrika Pengantar dan Aplikasinya, UPP STIM YKPN: Yogyakarta.

Yudhistira, M., \& Rachmawati, R. (2013). Pewilayahan Industri Kecil dan Rumah Tangga di Kabupaten Bantul. Jurnal Bumi Indonesia, 2(1): 177-185. 